\title{
A IMPORTÂNCIA DO LÚDICO NO ENSINO DE LÍNGUAS ESTRANGEIRAS
}

\author{
Ana Flávia Naves Resende Siquierolli - UFU \\ naves.anaflavia@gmail.com \\ Pedro Henrique Silveira - UFU \\ pedro.h.silveira63@gmail.com
}

Resumo: O desafio de ensinar e aprender neste século leva-nos a refletir sobre o papel da escola na formação dos cidadãos e a importância dos professores para a construção de uma prática educativa que supere os padrões tradicionais. O professor precisa possuir uma postura crítico-reflexiva e ser receptivo à utilização de novas metodologias Um dos grandes problemas enfrentados no ensino/aprendizagem de línguas estrangeiras é a desmotivação dos estudantes, portanto fazê-los se interessar por sua própria aprendizagem é um grande desafio. A motivação é aquilo que impulsiona alguém a fazer algo, aquilo que o põe em movimento em direção aos seus objetivos. Acreditamos que a utilização de atividades lúdicas em sala de aula contribui para o despertar do interesse e da motivação dos estudantes no aprendizado de línguas estrangeiras. O lúdico é um elemento facilitador da aprendizagem de línguas estrangeiras, sendo assim é excelente recurso pedagógico para auxiliar professores no ensino de línguas estrangeiras. O termo 'lúdico' tem a sua origem na palavra latina 'Iudus' e o termo dicionarizado se refere a jogo, brinquedo, divertimento. Em uma visão mais abrangente, o lúdico é eminentemente educativo e cultural, uma vez que com essa prática pode-se adquirir conhecimento. Piaget considera os jogos como meios que contribuem e enriquecem o desenvolvimento intelectual. Vygotsky valoriza o lúdico como ferramenta pedagógica fundamental ao desenvolvimento dos aspectos sociocognitivos dos estudantes, com o intuito de promover a motivação e aprendizagem mais significativa. Um ser que brinca e joga é, também, um ser que age, sente, pensa, aprende e se desenvolve. Ao brincar ele desenvolve suas potencialidades, adquire conhecimento e desenvolve a sociabilidade. O lúdico possibilita um ambiente favorável à aprendizagem, estimula a criatividade e auxilia as interações. O sistema de aprender brincando é inspirado na concepção de educação para além da instrução. Embasados nos estudos teóricos de Vygotsky e Piaget sobre ludicidade e aquisição da linguagem apresentaremos exemplos de atividades lúdicas e o seu efeito no processo de ensino/aprendizagem de línguas estrangeiras. Buscamos atividades motivadoras, como alternativa para atingir uma aprendizagem eficaz. Esperamos que esta comunicação, que tem por finalidade apresentar os benefícios da utilização de atividades lúdicas, possa contribuir para o repensar da prática pedagógica do professor de línguas estrangeiras.

O lúdico é uma das práticas utilizadas em diversas áreas de ensino e aprendizagem.

De acordo com o dicionário Houaiss (2004, p. 464) o lúdico se refere ao jogo ou 
divertimento, e proporciona um ambiente divertido e descontraído. Portanto, o jogo oferece à aula de língua estrangeira uma alternativa de interação e aprendizado.

O jogo não é somente relacionado aos momentos de aprendizagem. Branco (2015) defende que os jogos fazem parte das relações humanas desde os tempos primórdios. Jogamos por diversos motivos, seja por curiosidade, por diversão, por descontração ou até mesmo pela aprendizagem. Os jogos não são limitados a uma faixa etária, pois os motivos de se jogar são comuns a todos independentemente de idade, cor, sexo ou condição financeira.

Embora não seja considerada uma metodologia, podemos afirmar que o lúdico é uma técnica de ensino. Alguns autores defendem o seu uso, como Vygotsky (1998) que afirma: "As maiores aquisições de uma criança são conseguidas no brinquedo, aquisições que no futuro tornar-se-ão seu nível básico de ação real e moralidade" (Vygotsky, 1998 apud Zacharias, 2007, p. 6)

Piaget (1998) por sua vez diz que a atividade lúdica é o berço obrigatório das atividades intelectuais da criança, sendo assim, indispensável às práticas educativas. (Piaget, 1998 apud Zacharias, 2007, p. 1)

Portanto, o lúdico é um passo importante para o desenvolvimento da criança e que, obrigatoriamente, a criança passa por ele para conseguir realizar as atividades exigidas no cotidiano exterior à sala de aula.

As práticas lúdicas também permitem que o aluno tenha um espaço seguro para praticar e aprender, já que o lúdico propõe uma aprendizagem por meio de uma prática, e o aprendizado se faz de forma implícita. Sobre isso Branco (2015, p. 35) ainda acrescenta que através destas práticas lúdicas o aprendiz cria novas situações, inventa novos recursos e avalia-se de forma tolerante e positiva.

Sendo assim as atividades que envolvem o lúdico também estimulam a criatividade. Por meio da criatividade os alunos conseguem se colocar em situações imaginárias de uso da língua e em situações de comunicação em que deverão utilizar a língua alvo para se comunicarem.

Esse tipo de aprendizagem e uso da criatividade coloca o aluno como um participante ativo dentro da língua estrangeira e que a utiliza de forma autêntica para alcançar os objetivos da atividade, além de proporcionar interações que ultrapassam os limites do livro didático. 
Os jogos lúdicos também propiciam ao aluno a oportunidade de desenvolver suas práticas sociais e desperta no aluno atitudes como o respeito, a cooperação, o uso de regras, a iniciativa pessoal e a justiça. Vygotsky afirma que:

A criança que sempre participou de jogos e brincadeiras grupais saberá trabalhar em grupo; por ter aprendido a aceitar as regras do jogo, saberá também respeitar as normas grupais e sociais. É brincando bastante que a criança vai aprendendo a ser um adulto consciente, capaz de participar e engajar-se na vida de sua comunidade. (Vygotsky, 1994, p. 82-83 apud Correa, Bento, 2012, p.8).

Sendo assim compreende-se os jogos como uma prática que ultrapassa os limites da sala de aula e do conteúdo a ser ensinado, que não coloca o aluno como um receptor do conhecimento, mas sim, um agente ativo nas práticas de ensino e aprendizagem.

O ensino de línguas estrangeiras passou por várias fases a respeito das metodologias e abordagens, começando no ensino de gramática e tradução, passando pelo método direto, a inclusão de recursos auditivos e visuais na metodologia audiovisual, a abordagem comunicativa e inúmeras outras abordagens e metodologias de ensino.

Nesta trajetória o lúdico foi conquistando o seu espaço, que antes era nulo ou praticamente nenhum para uma prática recorrente nos dias atuais. Estas práticas foram sendo consideradas no ensino de línguas estrangeiras pela mudança do papel do professor e do papel do aluno.

Nas metodologias e abordagens, utilizadas recentemente, o foco principal é o aluno. Sendo assim, todas as questões relacionadas ao aluno são consideradas, como a sua realidade, as suas experiências de mundo, as suas relações pessoais e estilos de aprendizagem. Portanto, como dito anteriormente o papel do aluno é ativo neste processo de ensino e aprendizagem, e o professor se torna um facilitador para que o aluno alcance seus objetivos na língua estrangeira.

De acordo com as abordagens que prezam pela comunicação, os professores preparam os seus alunos e trabalham com habilidades que os colocam em situações reais, ou quase reais, de comunicação autêntica na língua estrangeira. Sendo assim, os jogos lúdicos se mostram como instrumentos de aprendizagem inseridos nestas abordagens. 
considerando, portanto, o lúdico uma forma de desenvolvimento psico-corporal, o seu uso implica em desenvolver atividades com diferentes partes do corpo e da mente.

Assim, Piaget (1978) estabelece três tipos de jogos, sendo que cada um deles é responsável por uma função no desenvolvimento do jogador.

O primeiro é o jogo sensório-motor que segundo Piaget

é um jogo cuja finalidade é o próprio prazer do funcionamento, constituise em repetição de gestos e movimentos simples como agitar os braços, caminhar, pular, e ao descobrir suas funções, há um sentimento de felicidade. (Piaget, 1978, p. 148 apud Correa, Bento, 2012, p.9)

Este tipo de jogo permite que os alunos utilizem o seu corpo para a construção de sentidos e como realizador de tarefas. Dentre as atividades que despertam o aspecto sensório-motor citamos: "o mestre mandou", que é uma atividade comum entre crianças e jovens, onde um líder do jogo, que poderia ser até mesmo o professor, pede aos alunos que realizem tarefas utilizando o seu corpo. O "mestre" poderia utilizar verbos e os alunos/jogadores iriam identificá-los e demonstrá-los por meio de ações utilizando os seus corpos. Por exemplo, quando se diz o verbo ler, os alunos deverão agir como se estivessem lendo algo. Esta atividade pode ser feita com alunos de todos os níveis, sendo que o professor deverá adequar a tarefa ao nível dos alunos.

Uma outra atividade é a canção "Cabeça, ombro, joelho e pé" que possui como objetivo fazer com que os alunos, ao cantarem e dançarem, reconheçam as partes do corpo humano na língua estrangeira. Esta música foi traduzida para diversas línguas e é uma atividade desenvolvida com alunos de níveis iniciantes. Alguns alunos adolescentes e adultos podem se mostrar contrários a esse tipo de atividade, caberá ao professor motivá-los o suficiente para que eles realizem a atividade.

Um outro tipo de jogo estabelecido por Piaget é o jogo simbólico que segundo ele,

Consiste em satisfazer o "eu" por meio de uma transformação do real em função dos desejos, ou seja, tem a função de assimilar a realidade, ela incorpora a seu mundo, objetos, pessoas ou acontecimentos significativos e os reproduz através de suas brincadeiras. Jogos de faz de conta que possibilita a criança sonhar e fantasiar revela angústias, conflitos e medos aliviando tensões e frustrações, são importantes para que se trabalhe diferentes tipos de sentimentos e a forma de lidarmos com eles. (Piaget, 1978, p. 148 apud Correa, Bento, 2012, p.9) 
Neste tipo de jogo é criado um ambiente em que o aluno/jogador se imerge na realidade construída dentro do jogo e cria situações de uso da língua estrangeira. No ensino de línguas estrangeiras este jogo pode ser utilizado frequentemente e de diversas maneiras.

Um exemplo de atividade é a construção de espaços para que o aluno simule ações como se estivesse em uma situação de sua vida cotidiana, porém utilizando a língua estrangeira. O professor pode, por exemplo, trazer peças de roupa para a sala de aula e os alunos deverão interagir como vendedores e clientes em uma loja de roupas, onde o vendedor informa a falta da peça desejada pelo cliente, as formas de pagamento possíveis, dentre outras informações da realidade desse contexto.

Outros exemplos que podem ser utilizados pelo professor são situações da vida cotidiana, como: compras de passagens, compras de supermercado, indicação de direções, consultas médicas e pedidos em restaurantes, lanchonetes e bares.

Para esta atividade, quanto maior a liberdade para criar situações o aluno tiver, maior será o grau de aprendizagem, já que ele deverá utilizar todo o seu arcabouço linguístico para desempenhar as funções da atividade, e não só estruturas definidas pelo professor.

Este tipo de atividade pode ser realizada com alunos de todos os níveis, com diferença no input que o professor oferecerá e na complexidade linguística utilizada pelo aluno na atividade.

O terceiro tipo de jogo estabelecido por Piaget é o jogo de regras que

se caracteriza pela existência de uma série de leis impostas pelo grupo, sendo que quem descumprir será penalizado, é uma forte competição pelos participantes, geralmente jogado em parceria e um conjunto de obrigações o que o faz tornar-se social, são importantes para que a criança entenda que nem sempre levamos vantagens, aprendendo assim a lidar com as emoções. (Piaget, 1978, p. 148 apud Correa, Bento, 2012, p.9)

Esta categoria de jogos é a de competição, em que por meio da língua estrangeira os alunos deverão cumprir tarefas sozinhos ou em equipes a fim de ganhar a competição. Como exemplo deste tipo de atividade podemos citar quizzes de conhecimento geral em que as perguntas são feitas na língua estrangeira. Desta forma os alunos não estarão preocupados e inseguros, como estariam ao fazer um 
exercício escrito, e trabalharão a oralidade na língua estrangeira de forma espontânea.

Este tipo de jogo, ainda dá a oportunidade de trabalhar com os alunos questões sociais como o ganhar e o perder em uma competição, a espera da vez, a paciência, e outras questões que contribuem para a formação social. Desta forma, o lúdico cria uma oportunidade de trabalhar com questões da formação do aluno como indivíduo de uma sociedade, as quais normalmente não são abordadas em uma aula de língua estrangeira.

Além dos quizzes mencionados podemos utilizar inúmeros outros jogos que poderão auxiliar no processo de ensino e aprendizagem e cumprirão a função desta categoria de jogos. Dentre estes jogos podemos citar: mímicas, dominó, bingo, jogos matemáticos, jogos de tabuleiro e charadas, que poderão ser utilizados de acordo com o conteúdo a ser trabalhado e o objetivo da aula proposta pelo professor.

Foram exemplificadas algumas atividades utilizando-se dos tipos de jogos estabelecidos por Piaget, no entanto uma mesma atividade pode ser utilizada em diferentes níveis da língua estrangeira e abordando diferentes conteúdos, cabe ao professor adequar a atividade ao grupo e às situações estudadas em sala de aula.

\section{Considerações Finais}

O lúdico é um importante instrumento de ensino e aprendizagem de línguas estrangeiras. Ele não está limitado a uma faixa etária, pois os motivos de praticá-lo são comuns a todos independentemente de idade, cor, sexo ou condição financeira.

Esta prática permite uma aula contextualizada e dá ao aluno a oportunidade de se expressar e utilizar a língua estrangeira de uma forma autêntica e objetiva mediante a instruções fornecidas pelo docente.

A função comunicativa é a competência mais desenvolvida com a utilização das práticas lúdicas, sendo assim o fulcro da utilização dos jogos na sala de língua estrangeira. É por meio de atividades (dinâmicas, músicas, competições), propostas em sala de aula, que proporcionam aos alunos a oportunidade de trabalhar e desenvolver a criatividade, a criticidade e as práticas sociais.

Devido ao caráter descontraído das atividades lúdicas, os professores devem ficar atentos aos seus objetivos no momento da realização dessas atividades, para 
que o propósito não se perca e a atividade, que tem função de aprendizagem, não se torne simplesmente uma brincadeira durante a aula.

\section{REFERÊNCIAS BIBLIOGRÁFICAS}

DA LÍNGUA PORTUGUESA, Minidicionário Houaiss. Organizado pelo Instituto Antonio Houaiss de Lexicografia e Bancos de Dados da Língua Portuguesa S/C Ltda.-2a . Ed. rev. e aum. Rio de Janeiro: Objetiva, 2004.

BRANCO, Olga Maria Teixeira Carvalho. A importância do lúdico para a aquisição do léxico na aprendizagem de uma segunda língua. 2015.

ZACHARIAS, Vera Lúcia Camara F. O lúdico na educação infantil. Endereço eletrônico: http://www. centrorefeducacional. com. br/ludicoeinf. htm, 2007.

CORREA, Leidiniz Soares, BENTO, Raquelo Matos de Lima. A IMPORTÂNCIA DO LÚDICO PARA APRENDIZAGEM NA EDUCAÇÃO INFANTIL. 2012. Trabalho de Conclusão de Curso. (Graduação em Pedagogia) - Faculdade Panamericana de JiParaná. 